\title{
IN VITRO BIOPHARMACEUTICAL AND PHYSICOCHEMICAL EVALUATION OF DIFFERENT BRANDS OF CIPROFLOXACIN MARKETED IN ADEN- YEMEN
}

\author{
WAFA F BADULLA*, DUA'A H AL-MAQDI AND EBTESAM S BAMAHMOOD \\ Department of Pharmaceutical Chemistry, Faculty of Pharmacy, Aden University, Aden, \\ Yemen
}

Published online: 23 November 2021

To cite this article: WAFA F BADULLA, DUA'A H AL-MAQDI \& EBTESAM S BAMAHMOOD (2021) In vitro biopharmaceutical and physicochemical evaluation of different brands of ciprofloxacin marketed in Aden-Yemen, Malaysian Journal of Pharmaceutical Sciences, 19(2): 73-86. https://doi.org/10.21315/mjps2021.19.2.5

To link to this article: https://doi.org/10.21315/mjps2021.19.2.5

\begin{abstract}
The current study conducted to evaluate the biopharmaceutical and physicochemical equivalence of the three available pharmaceutical dosage forms of ciprofloxacin (CIP) in the local markets (tablets, infusion and eye drops). Three brands for each dosage form were selected and coded as Tablets I, II, III; CIP infusion (Infusion I, II, III) and CIP eye drops (Eye drops I, II, III). Different in vitro quality control tests, physiochemical and determination of active ingredients contents were performed. All brands of tablets have a satisfactory result that complies with the pharmacopeia specification except the hardness of the tablets was more than the recommended value, and the salinity of Infusion II and III was lower than 0.9, the viscosity of the eye drops was lower than the specified value. Post-marketing surveillance is an essential issue to distinguish poor-quality medicines and must be routinely performed to weed out substandard and counterfeit medicine.
\end{abstract}

Keywords: Ciprofloxacin, Biopharmaceutical, Quality control tests, Physicochemical, Pharmacopeia

\section{INTRODUCTION}

Ciprofloxacin (CIP) is a synthetic antibacterial of the fluoroquinolones' group. It has a concentration-dependent bactericidal effect (Hamam 2014). It is effective for urinary, respiratory and gastrointestinal tracts, soft tissue, and sexual infections (Rao and Nagaraju 2004; Lode and Allewelt 2002; Bedor et al. 2007). It is one of the most prescribed antibiotics by physicians in Yemen.

"Corresponding author: aden.wf.77@gmail.com

(c) Penerbit Universiti Sains Malaysia, 2021. This work is licensed under the terms of the Creative Commons Attribution (CC BY) (http://creativecommons.org/licenses/by/4.0/). 
There are many brands of CIP circulating in the Aden-market. The quality of the pharmaceuticals' is an essential part to ensure that the drugs are safe, efficient, suitable for their intended use, conform with the condition of the marketing authorisation and not harm to the consumers. Like many developing countries some of the marketed drugs in this city are substandard, falsified or counterfeits. Many reasons contributed to the entrance of low-quality drugs such as market forces, getting medicines at affordable prices due to lowincome of most people, and inadequate resources for regulating and controlling the quality of pharmaceutics on the market. However, low-quality medicines pose many hazards to public health and many of them are sold without control particularly in developing countries (Pecoul et al.1999; WHO 2005).

The World Health Organization (WHO) stated guidelines for worldwide standard and specification for the registration, assessment, marketing, authorisation and quality control of generic medicinal products (WHO 2005; 1996). As reported in a previous study carried out in Aden city, $40 \%$ were fake or of low quality and $80 \%$ of medications pass into the country through illegal routes (Sallami et al. 2017). Also, storage conditions play an important role in drug stability. Due to the continuous shortage of electricity in this city, high temperature and humidity may lead to the decomposition of the active ingredients. Consequently, the aforementioned problems lead to deny the patients safe and effective therapy, expose patients to noxious impurities, participate in microorganism resistance, increased mortality and morbidity (Cockburn et al. 2005; Johnston and Holt 2014).

The primary physicochemical evaluation of medications has a significant indication of the quality of drug products. The bioavailability and bioequivalence of oral solid dosage forms in vivo can be estimated by in vitro dissolution testing (Itiola and Pilpel 1996).

The literature on the post-marketing surveillance of CIP in Yemen shows the presence of a study carried out in Sana'a City only for tablet dosage forms. The study indicated that all tested brands confirmed the pharmacopeia's specifications (Alyahawi and Alsaifi 2018). The current study conducted to evaluate the biopharmaceutical and physicochemical equivalence of the three available pharmaceutical dosage forms in the local markets (tablets, infusion and eye drops).

\section{METHODS}

\section{Drugs and Chemicals}

The standard of CIP-hydrochloride $(\mathrm{HCl})$ was given as a gift from the Modern pharmaYemen. Three commercially available brands of CIP for each dosage form were purchased from local community pharmacies in Aden. The most widely prescribed brands were selected, information related to them is summarised in Table 1. The brands were coded as I, II, III. Other chemicals were of analytical grads. 
Table 1: Different brands of CIP dosage forms.

\begin{tabular}{|c|c|c|c|}
\hline Brand code & Made in & Strength & $\begin{array}{l}\text { Manufacture (Mfg) \& } \\
\text { expire (Exp) dates }\end{array}$ \\
\hline \multicolumn{4}{|c|}{ Brands of CIP tablets } \\
\hline Tablet-I & Germany & $500 \mathrm{mg}$ & $\begin{array}{l}\text { Mfg. Aug. } 2018 \\
\text { Exp. Jul. } 2021\end{array}$ \\
\hline Tablet-II & India & $500 \mathrm{mg}$ & $\begin{array}{l}\text { Mfg. Mar. } 2018 \\
\text { Exp. Feb. } 2021\end{array}$ \\
\hline Tablet-III & Yemen & $500 \mathrm{mg}$ & $\begin{array}{l}\text { Mfg. Apr. } 2017 \\
\text { Exp. Apr. } 2020\end{array}$ \\
\hline \multicolumn{4}{|c|}{ Brands of CIP infusion } \\
\hline Infusion-I & India & $2 \mathrm{mg} / \mathrm{mL}$ & $\begin{array}{l}\text { Mfg. Jul. } 2017 \\
\text { Exp. Jun. } 2020\end{array}$ \\
\hline Infusion-II & India & $2 \mathrm{mg} / \mathrm{mL}$ & $\begin{array}{l}\text { Mfg. Apr. } 2018 \\
\text { Exp. Mar. } 2021\end{array}$ \\
\hline Infusion-III & India & $2 \mathrm{mg} / \mathrm{mL}$ & $\begin{array}{l}\text { Mfg. Nov. } 2018 \\
\text { Exp. Oct. } 2021\end{array}$ \\
\hline \multicolumn{4}{|c|}{ Brands of CIP eye drop } \\
\hline Eye drop-I & Turkey & $0.3 \%$ & $\begin{array}{l}\text { Mfg. Feb. } 2019 \\
\text { Exp. Feb. } 2021\end{array}$ \\
\hline Eye drop-II & $\begin{array}{l}\text { Saudi } \\
\text { Arabia }\end{array}$ & $0.3 \%$ & $\begin{array}{l}\text { Mfg. May. } 2018 \\
\text { Exp. May. } 2020\end{array}$ \\
\hline Eye drop-III & India & $0.3 \%$ & $\begin{array}{l}\text { Mfg. Sep. } 2018 \\
\text { Exp. Aug. } 2021\end{array}$ \\
\hline
\end{tabular}

\section{Instruments}

The information related to the instruments used in this study is listed in Table 2.

Table 2: List of instruments.

\begin{tabular}{|c|c|c|c|c|c|}
\hline No. & Instrument & Made in & No. & Instrument & Made in \\
\hline 1 & Conductometer & $\begin{array}{l}\text { Inolabcond level } \\
2, \text { Germany }\end{array}$ & 10 & $\begin{array}{l}\text { Electronic } \\
\text { shaker }\end{array}$ & $\begin{array}{l}\text { Patterson Scientific LTD, } \\
\text { Germany, KS130 }\end{array}$ \\
\hline 2 & Disintegration tester & $\begin{array}{l}\text { Pharma-Test- } \\
\text { PTZ-Germany }\end{array}$ & 11 & $\begin{array}{l}\text { Friability } \\
\text { tester }\end{array}$ & $\begin{array}{l}\text { THERMONIK, Campbell } \\
\text { Electronics, Mumbai, India }\end{array}$ \\
\hline 3 & Dissolution tester & $\begin{array}{l}\text { ERWEKA, } \\
\text { Germany }\end{array}$ & 12 & $\begin{array}{l}\text { Hardness } \\
\text { tester }\end{array}$ & PTB 311F, Germany \\
\hline 4 & Electronic balance & $\begin{array}{l}\text { A\&D company } \\
\text { LTD, Japan, } \\
\text { HR-250 }\end{array}$ & 13 & $\begin{array}{l}\text { Thickness } \\
\text { and diameter } \\
\text { tester }\end{array}$ & PTB 311F, Germany \\
\hline 5 & Electrical oven & $\begin{array}{l}\text { VACIOTEM-T } \\
\text { SELECTA, Spin }\end{array}$ & 14 & $\begin{array}{l}\text { UV-visible } \\
\text { spectroscopy }\end{array}$ & $\begin{array}{l}\text { Lasany }^{\circledR} \text { advanced } \\
\text { microprocessor UV- } \\
\text { VIS-L1-295 }\end{array}$ \\
\hline 6 & $\mathrm{pH}$ meter & $\begin{array}{l}\text { Inolab WTW, } \\
\text { Germany }\end{array}$ & 15 & Ultrasonic & ROHS, China, 031 \\
\hline
\end{tabular}




\section{Methodology for Tablets}

\section{Weight variation test}

The test conducted as stated in the United States Pharmacopeia-National Formulary (USPNF) weight variation test. Twenty tablets from each brand were weighed individually by using an analytical balance. The average weight for each brand, as well as percentage deviations, were calculated by using the following formula.

$$
\text { Weight variation }=\frac{A_{w} \times \%}{100}
$$

where

$A_{w}=$ Average weight of the tablet Upper limit $=A_{w}+$ Weight variation

Lower limit $=A_{w}-$ Weight variation

The tablet complies with the test if not more than two of the individual weights deviate from the average weight by more than $5 \%$. allowed:

Furthermore, calculate the upper and lower limits at double the $\%$ difference

Upper limit $=A_{w}+[(2 \times \% / 100)(\mathrm{W})]$

Lower limit $=A_{w}-[(2 x \% / 100)(\mathrm{W})]$

After that, the individual weights of tablets were compared to the upper and lower limits calculated at the \% difference allowed and at double that percentage (Uddin et al., 2015; Uduma et al. 2011).

\section{Diameter and thickness test}

Tablet diameters and thickness were determined with a micrometre. Twenty tablets are dusted then individually placed between the calipers of the micrometre using forceps. The instrument gave a visual reading of tablet thickness. The allowed limit of thickness variation is $\pm 5 \%$ of the size of the tablet.

\section{Friability test}

The evaluation of friability was carried out by Roche friabilator. It was performed by weighing 20 tablets $\left(w_{1}\right)$ by placing them in the apparatus. The apparatus was rotated at a speed of $25 \mathrm{rpm}$ per minute for $4 \mathrm{~min}$. The tablets are exposed to rolling and operated shocks resulting from free falls within the apparatus. The tablets were dedusted and reweighed $\left(w_{2}\right)$. The weight difference and percentage friability were calculated. According to USP-NF, weight loss should not be more than 1\% (Swarbrick 2007; British Pharmacopeia 2016).

Percentage friability was calculated as:

$$
\text { Percentage friability }=\frac{W_{1}-W_{2}}{W_{1}} \times 100
$$




\section{Hardness test}

To perform this test, a tablet was placed in electrically-operated hardness tester and the crushing strength that just causes the tablet to break is recorded. The procedure was repeated for 20 tablets. The acceptable limit for this test is $6 \pm 2 \mathrm{~kg} / \mathrm{cm}^{2}$.

\section{Disintegration test}

This test was performed by taking six tablets from each brand and placing it in the disintegration apparatus. The time required for tables to break and pass through the sieve was taken as disintegration time. The test performed by placing one tablet in each tube form each brand and the basket rack was sited in a $1000 \mathrm{~mL}$ vessel encompassing $900 \mathrm{~mL}$ of water reserved at $37 \pm 2^{\circ} \mathrm{C}$. The basket holding the tablets was moved up and down through a distance of 5-6 cm at a frequency of 28-32 cycles per min. Perforated plastic discs were placed over each tablet to prevent floating. The apparatus was worked for $30 \mathrm{~min}$. To obey the USP-NF standards, the tablets must fragment and all particles must pass via the10-mesh screen within $30 \mathrm{~min}$. The residue remains should have a soft mass with no firm coated (Uduma et al. 2011; Swarbrick 2007).

\section{Dissolution test}

The dissolution test was carried out according to British Pharmacopeia (BP) (apparatus II [paddle method]). The dissolution medium was $900 \mathrm{~mL}$ of water which was maintained at $37 \pm 0.5^{\circ} \mathrm{C}$. The rotational speed of the apparatus was adjusted at $50 \mathrm{rpm}$. After $30 \mathrm{~min}$, a $10 \mathrm{~mL}$ sample of the medium was withdrawn. After filtration, $0.5 \mathrm{~mL}$ of filtrate was taken and diluted to $50 \mathrm{~mL}$ with distilled water and measured the absorbance at the maximum at $278 \mathrm{~nm}$, using dissolution medium in the reference cell. The percentage then calculated by comparing with the absorbance of standard CIP solution in water at the maximum at $278 \mathrm{~nm}$ using dissolution medium in the reference cell. The amount of CIP released is not less than $80 \%$ of the stated amount (British Pharmacopeia 2016).

\section{Methodology for Infusions and Eye Drops}

\section{Measurement of $\mathrm{pH}$}

Approximately, $5-10 \mathrm{~mL}$ of the infusion and eye drops were put into a beaker. Then the $\mathrm{pH}$ of the infusion and eye drops samples was measured using $\mathrm{pH}$ meter, having an automatic temperature compensation (ATC) probe. The $\mathrm{pH}$ meter was calibrated using standard buffer solutions of $\mathrm{pH} 4.01,7.00$ and 10.01 , before the measurements.

\section{Total dissolved solids (TDS), conductivity and salinity}

An increment of infusion and eye drops was taken into a small beaker and then parameters measured using conductometer. The same steps were repeated in measuring the remaining six samples. The measurement was carried in quintuplicate. 


\section{Density and specific gravity}

The empty density bottle was washed with acetone weighed by using the electrical balance, then filled with water and weighed. After that, the bottle was washed with acetone and filled with infusion and weighed. The density and specific gravity were calculated. Then each of the remaining samples was weighed three times and the average was taken and density and specific gravity were calculated.

$$
\text { Density }(\rho)=\frac{w_{3}-w_{1}}{w_{2}-w_{1}}-\times \rho_{\text {st }}
$$

where

$w_{1}=$ weight of the empty bottle

$w_{2}=$ weight of bottle with water

$w_{3}=$ weight of the bottle with the sample

$\rho_{\text {st }}=$ density of water at $25^{\circ} \mathrm{C}(0.99602 \mathrm{~g} / \mathrm{mL})$

\section{Viscosity}

Ostwald was fixed on the holder and the time required for the fluid to pass the Ostwald was measured using the stopwatch. First, it was started with water as a standard solution with known viscosity and repeated three times. Then the same procedure was carried out for samples and calculated individually by the aid of density results which discussed previously.

$$
\operatorname{Viscosity~}(\eta)=\eta_{\mathrm{w}} \frac{t_{\text {liq }} \rho_{\text {liq }}}{t_{\mathrm{w}} \rho_{\mathrm{w}}}
$$

where

$t_{\text {liq }}=$ time of liquid

$\rho_{\text {liq }}=$ density of liquid

$t_{\mathrm{w}}=$ time of water

$\rho_{w}=$ density of water

$\eta_{\mathrm{w}}=$ viscosity of water

\section{Determination of sodium chloride content in CIP infusion}

Transfer $10 \mathrm{~mL}$ of sample solution to a suitable container, dilute with water to $150 \mathrm{~mL}$, add $1.5 \mathrm{~mL}$ of potassium chromate $(10 \%)$, and titrate with $0.1 \mathrm{~N}$ silver nitrate. Each $\mathrm{mL}$ of $0.1 \mathrm{~N}$ silver nitrate is equivalent to $5.844 \mathrm{mg}$ of sodium chloride $(\mathrm{NaCl})$. Acceptance criteria: 85.5-94.5 mg (US Pharmacopeia 2016).

\section{Drug content}

A stock standard solution containing $50 \mu \mathrm{g} / \mathrm{mL}$ CIP-HCl was prepared by dissolving $10 \mathrm{mg}$ of standard in water and diluting to the mark in a $200 \mathrm{~mL}$ calibrated flask. A series of CIP-HCl $(3.5-11.5 \mu \mathrm{g} / \mathrm{mL})$ were prepared and examined at max absorbance of $278 \mathrm{~nm}$ (Naveed and Waheed 2014). The procedure carried for tablet dosage forms, by weighing and then the average weight of ten tables was taken as the correct value. The tablets were

Malay J Pharm Sci, Vol. 19, No. 2 (2021): 73-86 
grained into a fine powder. An amount of the powder equivalent to the mean weight of one tablet was dissolved with $100 \mathrm{~mL}$ water (milli-Q) and sonicated for $10 \mathrm{~min}$. The stock is further diluted to get the final concentration equal to $7.5 \mu \mathrm{g} / \mathrm{mL}$, the solution was filtered before measuring the absorbance. A volume of CIP infusion and eye drop was diluted to get the final concentration equal to $6.0 \mu \mathrm{g} / \mathrm{mL}$. The content was mixed and examined by spectroscopy.

\section{RESULTS}

Data of each performed test for each brand was recorded in MS-Exce ${ }^{\otimes}$ sheet and analysed.

\section{Evaluation of Tablet Dosage Forms}

The average weight and weight deviation of the different brands of CIP tablets are shown in Table 3. All tablets of all brands were conformed with the specification of USP for uniformity of weight which states that for tablets weighing more than $324 \mathrm{mg}$, the weight of not more than two tablets should not differ from the average weight by more than $5 \%$ (US Pharmacopeia 2007). All tablets length and thickness were within the recommended limits as it is represented in Table 3. The mean values of the friability of the various brands of CIP tablets examined shown in Table 3.

Table 3: Some quality control parameters for CIP tablets.

\begin{tabular}{llclll}
\hline Brand & $\begin{array}{l}\text { Average weight } \\
\text { (gm), \%RSD }\end{array}$ & $\begin{array}{l}\text { Hardness (kg/ } \\
\mathbf{c m}^{2} \text { \% RSD }\end{array}$ & $\begin{array}{l}\text { Friability } \\
\text { (\%) }\end{array}$ & $\begin{array}{l}\text { Thickness(mm), } \\
\text { \%RSD }\end{array}$ & $\begin{array}{l}\text { Length }(\mathbf{m m}), \\
\text { \%RSD }\end{array}$ \\
\hline Tablet-I & $0.7476 \pm 1.91$ & $27.90 \pm 0.25$ & 0.013 & $6.552 \pm 2.06$ & $17.220 \pm 0.058$ \\
Tablet-II & $0.8648 \pm 0.97$ & $30.48 \pm 0.12$ & 0.115 & $6.192 \pm 0.43$ & $19.404 \pm 0.182$ \\
Tablet-III & $0.6909 \pm 1.58$ & $30.47 \pm 0.15$ & 0.337 & $5.257 \pm 2.33$ & $18.30 \pm 0.046$ \\
\hline
\end{tabular}

Note: $\mathrm{RSD}=$ relative standard deviation

The mean values of the disintegration of the different brands of CIP tablets tested are shown in Table 4. The data of disintegration time ( $\mathrm{min}$ ) of CIP tablets were ranging from 1.20-7.31 min.

The data of the dissolution test are presented in Table 4. The obtained dissolution content at $30 \mathrm{~min}$ was within the range stated in pharmacopeias which stated that not less than $80 \%$ of the drug must be released. All the brands of the CIP tablets complied with the official specification for content uniformity.

Table 4: Result of dissolution test and disintegration time for CIP tablets.

\begin{tabular}{lll}
\hline Brand & Disintegration time, RSD & Dissolution test \%, RSD \\
\hline Tablet-I & $1.20 \pm 0.12$ & $97.68 \pm 0.72$ \\
Tablet-II & $6.11 \pm 0.24$ & $94.48 \pm 1.93$ \\
Tablet-III & $7.31 \pm 0.43$ & $86.55 \pm 2.47$ \\
\hline
\end{tabular}

Note: RSD = relative standard deviation 


\section{Evaluation of CIP Infusion and Eye Drops}

All examined infusion of CIP was containing $\mathrm{NaCl}$, so to determine its concentration, an aliquot of infusion was titrated by using $\mathrm{AgNO}_{3}$. The result of titration of all infusion brands was within the limit of $95 \%-105 \%$. The result is shown in Table 5 . The result of evaluating the viscosity revealed that all brand has a viscosity less than $1 \mathrm{cp}$ which equal to $1 \mathrm{mPa} / \mathrm{s}$ as represented in Table 5 .

All examined brands' pH was within the permitted limit. In the case of infusion, the allowed limit according to $\mathrm{BP}$ and USP is $\mathrm{pH} 3.9-4.5$ and $\mathrm{pH}$ 3.3-3.9. In vitro experiments have demonstrated that solution $\mathrm{pH}$ values of 2.3 and 11.0 kill venous endothelium cells on contact. The nearer the $\mathrm{pH}$ value is to 7.4 , the less the damage that occurs. However, all brands showed compatibility with the BP limits. The salinity of infusion should be 0.9 to be isotonic with blood, however, the only brand that showed this value was Infusion-I while the other two brands' values were 0.74 and 0.69 for Infusion-II and Infusion-III. The results are illustrated in Table 5.

Table 5: The physicochemical properties of CIP infusion and eye drops.

\begin{tabular}{lllllll}
\hline Property \pm RSD & $\begin{array}{l}\text { Infusion- } \\
\text { I }\end{array}$ & $\begin{array}{l}\text { Infusion- } \\
\text { II }\end{array}$ & $\begin{array}{l}\text { Infusion- } \\
\text { III }\end{array}$ & $\begin{array}{l}\text { Eye drop- } \\
\text { I }\end{array}$ & $\begin{array}{l}\text { Eye drop- } \\
\text { II }\end{array}$ & $\begin{array}{l}\text { Eye drop- } \\
\text { III }\end{array}$ \\
\hline $\mathrm{NaCl} \%$ & $97.56 \pm$ & $95.90 \pm$ & $95.57 \pm$ & - & - & - \\
& 0.59 & 1.04 & 1.21 & & & \\
Density $(\mathrm{gm} / \mathrm{mL})$ & $1.04 \pm$ & $1.043 \pm$ & $1.054 \pm$ & $1.056 \pm$ & $1.046 \pm$ & $0.955 \pm$ \\
& 0.002 & 0.002 & 0.004 & 0.093 & 0.386 & 0.006 \\
Sp. Gr & $1.009 \pm$ & $1.009 \pm$ & $1.01 \pm$ & $0.995 \pm$ & $1.003 \pm$ & $1.004 \pm$ \\
& 0.002 & 0.002 & 0.002 & 0.051 & 0.005 & 0.002 \\
Viscosity (cP) & $0.897 \pm$ & $0.973 \pm$ & $0.963 \pm$ & $0.977 \pm$ & $0.986 \pm$ & $0.860 \pm$ \\
& 1.91 & 1.84 & 1.06 & 1.81 & 0.799 & 1.419 \\
pH & $4.54 \pm$ & $4.52 \pm$ & $4.57 \pm$ & $4.80 \pm 0.72$ & $4.65 \pm 0.54$ & $4.45 \pm$ \\
& 0.127 & 0.49 & 0.22 & & & 0.79 \\
Salinity & $0.91 \pm$ & $0.74 \pm$ & $0.69 \pm$ & $0.4 \pm 0.00$ & $0.01 \pm 0.00$ & $0.30 \pm$ \\
& 0.64 & 0.78 & 0.00 & & & 0.00 \\
Conductivity & $2.11 \pm$ & $1480.33 \pm$ & $4.64 \pm$ & $1187 \pm$ & $13.13 \pm$ & $1106 \pm$ \\
(ms/cm) & 0.98 & 0.04 & 1.39 & 0.47 & 0.44 & 1.00 \\
TDS (mg/mL) & $1512 \pm$ & $74166 \pm$ & $916.67 \pm$ & $814.33 \pm$ & $9.00 \pm 0.00$ & $761.33 \pm$ \\
& 0.07 & 0.21 & 0.70 & 0.07 & & 0.15 \\
\hline
\end{tabular}

Note: $\mathrm{RSD}=$ relative standard deviation; TDS = total dissolved solids

The result of the determination of CIP content by using UV-spectroscopy revealed that all brands were within the permitted limits. The result is represented in Table 6.

Table 6: Results of assay of pharmaceutical dosage forms by the UV-method.

\begin{tabular}{ll}
\hline Brand & Content \pm SD \\
\hline Tablet-I & $102.0 \pm 0.77$ \\
Tablet-II & $101.6 \pm 0.89$ \\
\hline & (continued on next page)
\end{tabular}

Malay J Pharm Sci, Vol. 19, No. 2 (2021): 73-86 
Table 6: (continued)

\begin{tabular}{ll}
\hline Brand & Content \pm SD \\
\hline Tablet-III & $100.3 \pm 1.250$ \\
Infusion-I & $101.9 \pm 0.57$ \\
Infusion-II & $101.6 \pm 0.41$ \\
Infusion-III & $101.9 \pm 0.55$ \\
Eye drop-I & $102.4 \pm 0.72$ \\
Eye drop-II & $103.6 \pm 0.61$ \\
Eye drop-III & $102.1 \pm 1.03$ \\
\hline
\end{tabular}

\section{DISCUSSION}

\section{Evaluation of Tablet Dosage Forms}

Any medicine, to be effective and safe, must possess all the characteristics of high quality that are compatible with the international pharmacopeias. According to the Pharmaceutical Manufacturers Association of U.S., "quality is the sum of all the factors which contribute directly or indirectly to the safety, effectiveness, and acceptability of the product" (Verpoorte and Mukherjee 2003). The percentage, quality and pureness of chemically and biopharmaceutical equivalent medicines should be identical. The content uniformity, disintegration and dissolution rates must be comparable (Dressman et al. 1998).

The uniformity of the weight of the tablet is a sign of good manufacturing practice (GMP) as well as the quantity of active pharmaceutical ingredients. Weight difference may result in an erratic therapeutic response (Gennaro 2000). The results from this study are similar to the previous study carried out by Alyahawi and Alsaifi (2018), where uniformity of weight was between $679.3 \mathrm{mg} \pm 2.63 \%$ and $842.7 \mathrm{mg} \pm 3.58 \%$, indicated that all examined brands complied with the compendial specification for uniformity of weight.

The hardness test of the tablets is stated as a non-compendial test. It is a significant standard for tablets to resist fragmentation, abrasion or cracking under conditions of storage, transport and handling before storage (Rawlins 1977). It may also influence other characteristics such as friability and disintegration and dissolution release rate (Lachman, Liberman and Kanig 1986). Tablet hardness can be related to the difference in the criteria of excipients involved in the production formula of the different brands. Hardness values did not relate to friability values (Merchant et al. 2006). The limit range of hardness is between 4 and $10 \mathrm{~kg} / \mathrm{cm}^{2}$ (US Pharmacopeia 2007). The mean values of the hardness of the various brands of CIP tablets are illustrated in Table 3. Average hardness was found in the range of $27.90 \mathrm{~kg} / \mathrm{cm}^{2}$ to $30.48 \mathrm{~kg} / \mathrm{cm}^{2}$. The results indicated that all brands of CIP tablets were not in the limit. However, the current result is parallel with the previous study in Yemen which was between $20.03 \mathrm{~kg} / \mathrm{cm}^{2}$ and $31.535 \mathrm{~kg} / \mathrm{cm}^{2}$ (Alyahawi and Alsaifi 2018). Tablet hardness is not a definitive indicator of the tablet strength because the power of tablets when pressed to very hard tablets, may lose their crown part. Therefore, another parameter of the tablet strength, its friability is required. The loss due to abrasion is a measure of the tablet friability. The pharmacopeia states that the friability value of tablets should be not more than $1 \%$ and as such, all the brands of CIP were passed this friability specification (US Pharmacopeia 
2007). The Tablet-I had a low value that means the highest resistance to abrasion. The result is similar to the previous study in Yemen with the friability range between $0.01 \%$ and $0.37 \%$.

Tablet disintegration time is one of the very important physicochemical characteristics in solid dosage forms. The disintegration test measures the time required for tablets to disintegrate into particles. This is a significant condition for dissolution could be the rate-determining step in the drug absorption step. Disintegration must be directly correlated to the dissolution and consequently with the bioavailability of the drug (Niazi 2007). All brands of the CIP tablets compliment the pharmacopeia requirements which specify a disintegration time of not more than 15 min for uncoated tablets, while the USP requirement for disintegration is $30 \mathrm{~min}$ both for uncoated and film-coated tablets. All the brands complied with both BP and USP stipulations.

The dissolution test is also vital parameters that specified the release of medicine from the dosage form and be accessible for subsequent gastrointestinal tract (GIT) absorption at a specific time. This test is considered a sensitive test for distinguishing between formulations of the same medicine (Hsu and Ayres 1989; Bruntion 1991). The proposed therapeutic effect would not be obtained if the medicine has a poor dissolution profile (Giri et al. 2012). Dissolution testing, a surrogate marker for bioequivalence test, is a very practical and economic approach to identify bioavailability problems and evaluate the need for in vivo bioavailability (Shah 2001). Consequently, the in vitro dissolution is a vital tool in measuring the in vivo performance and also helps to recognise unacceptable or sub-standard drug products. Delay of the release of drugs from the tablet may lead to the sub-therapeutic level of the drug in plasma resulting in the retardation in the onset of action or short duration of action or no therapeutic action. Furthermore, the sub-therapeutic level of antibiotic in the body could be a cause for the development of drug resistance, a major problem of antibiotics (Campoli-Richards et al.1988; Hyatt, Nix and Schentag 1994).

All the brands of the CIP tablets complied with the official specification for content uniformity. Of note, the Tablets-I and -II were completely dissolved while in the case of Tablet-III, the tablets were not completely dissolved a small palpable part remained after $30 \mathrm{~min}$. The result from the previous study carried in Yemen was more than $80 \%$ drug release after $30 \mathrm{~min}$.

\section{Evaluation of CIP Infusion and Eye Drops}

The content of $\mathrm{NaCl}$ was determined as part of the quality control of the IV dosage form. Usually, $\mathrm{NaCl}$ is added to the IV solution to preserve its osmolarity. $\mathrm{NaCl} 0.9 \%$ solution is iso-osmotic with blood and the venous endothelium; the solution leads to no movement of water into or out of endothelial cells. Cellular damage does not occur when endothelial cells contact an iso-osmotic solution. The result of titration of all infusion brands was within the limit of $95 \%-105 \%$.

In the preparation of ophthalmic solutions, an appropriate thickening agent is often added to increase the viscosity. Although they lessen surface tension significantly, their main advantage is to rise the ocular contact time, thus reducing the drainage rate and increasing drug bioavailability and control the rate at which the drop flows out of the container (and thus enhance ease of application). The other advantage of most of the thickening agents is a lubricating effect. For instance, it has been revealed that the holding of an aqueous solution within the precorneal region is short (frequently less than $1 \mathrm{~min}$ ); but, if the viscosity is increased, the retention may be enhanced. The optimal viscosity for ophthalmic solutions is in the range of 15-25 centipoises (cp) (Allen, Popovich and Ansel 2005; Gibson 2007). The corneal contact time of topical ophthalmic solutions increases

Malay J Pharm Sci, Vol. 19, No. 2 (2021): 73-86 
with the viscosity of the formulations up to $20 \mathrm{cp}$. Additional increases lead to reflex tearing and blinking to recover the original viscosity of the lacrimal fluid $(1.05-5.97 \mathrm{cp})$. The result from this study showed that all brand has a viscosity less than one $\mathrm{cp}$ which equal to one $\mathrm{mPa} / \mathrm{s}$, that means all brands viscosity is below the allowed limit maybe because viscosity is formulation dependent, it is not part of an official monograph for ophthalmic products but it is part of the manufacturer's specification of the drug product.

The $\mathrm{pH}$ scale is a measurement of the concentration of hydrogen ions $\left(\mathrm{H}^{+}\right)$in a solution. The normal physiological pH of the ocular surface in humans is noted to be 7.11 \pm 1.5 . Control of pH by the addition of buffers is essential not only for comfort but also for drug stability and solubility. Because the buffering capacity of tear fluid is very low, ophthalmic formulations contain excipients that maintain a pH range of 4.75 to 7.40 . The recommended $\mathrm{pH}$ value for the CIP eye drops form BP and USP is 3.9-4.5 and 3.5-5.5, respectively (British Pharmacopeia 2016; US Pharmacopeia 2016). However, all brands showed compatibility with the BP limits.

Generally, a range of $0.5 \%$ to $2 \%$ saline tonicity is well-tolerated. Irritating hypertonic solutions can induce tearing, which increases tear outflow and decreases the concentration and efficacy of the drug in the tears, while hypotonic solutions are often used effectively in tear substitutes to compensate for the high tonicity in the tears of dryeye subjects (WHO 2018). The salinity of infusion should be 0.9 to be isotonic with blood, however, the only brand that showed this value was Infusion-I while the other two brands' values were 0.74 and 0.69 for Infusion-II and Infusion-III. There are no literature limits for the TDS and conductivity for eye drops and infusion. The results of these parameters are illustrated in Table 5.

As stated in the USP, CIP content should contain not less than $90 \%$ and not more than $110 \%$ and according to BP, the allowed range is $95 \%-105 \%$. The result revealed that all brands were within the permitted limits.

\section{CONCLUSION}

The objective of the present study was the evaluation of the quality control characteristics of the different pharmaceutical dosage forms of CIP present in Aden-Yemen markets. All the dosage forms displayed homogeneity in terms of the active ingredient, and other in vitro quality control tests. However, all tablets showed the hardness value that exceeds the recommended specification. The value of the salinity of two infusion dosage forms was lower than 0.9 , as well as, the viscosity of the eye drops was lower than one. The in confirmation of these parameters may be due to the effect of the formulation ingredients which have a significant influence on the quality parameters and physicochemical properties (OforiKwakye, Osei-Yeboah and Kipo 2010). Post-marketing surveillance is a must to weed out substandard and counterfeit medicine from the local markets.

\section{ACKNOWLEDGEMENTS}

The authors acknowledge the help of the Supreme Board of the Drug and Medical Appliances in Aden and its staff and Bachelor graduation students for their contribution to the accomplishment of this study. 


\section{REFERENCES}

ALLEN, L. V., POPOVICH, N. G. \& ANSEL, H. C. (2005) Ansel's pharmaceutical dosage forms and drug delivery systems, pp. 540-569 (Baltimore: Lippincott Williams \& Wilkins).

ALYAHAWI, A. \& ALSAIFI, A. (2018) Quality control assessment of different brands of ciprofloxacin $500 \mathrm{mg}$ tablets in Yemen, Universal Journal Pharmaceutical Research, 3(4): 31-36.

BEDOR, D. C. G., GONÇALVES, T. M., BASTOS, L. L., SOUSA, C. E. M. D., ABREU, L. R. P. D., OLIVEIRA, E. D. J. et al. (2007) Development and validation of a new method for the quantification of norfloxacin by HPLC-UV and its application to a comparative pharmacokinetic study in human volunteers, Revista Brasileira de Ciências Farmacêuticas, 43(2): 231-238. https://doi.org/10.1590/S1516-93322007000200009

BRITISH PHARMACOPEIA (2016) Ciprofloxacin tablets, volume III, pp. 327-328 (London: Medicines and Healthcare Products Regulatory Agency).

BRUNTION, L. L. (1991) The pharmacological basis of therapeutics, $8^{\text {th }}$ edition, pp. 926928 (New York: Pergamon Press).

CAMPOLI-RICHARDS, D. M., MONK, J. P., PRICE, A., BENFIELD, P., TODD, P. A. \& WARD, A. (1988) Ciprofloxacin: A review of its antibacterial activity, pharmacokinetic properties and therapeutic use, Drugs, 35(4): 373-447.

COCKBURN, R., NEWTON, P. N., AGYARKO, E. K., AKUNYILI, D. \& WHITE, N. (2005) The global threat of counterfeit drugs: Why industry and governments must communicate the dangers, PLoS Medicine, 2: 302-308. https://doi.org/10.1371/journal.pmed.0020100

DRESSMAN, J. B., AMIDON, G. L., REPPAS, C. \& SHAH, V. P. (1998) Dissolution testing as a prognostic tool for oral drug absorption: Immediate release dosage forms, Pharmaceutical Research, 15(1): 11-22. https://doi.org/10.1023/A:1011984216775

GENNARO, A. R. (2000) Remington: The science and practice of pharmacy, $20^{\text {th }}$ edition (New York: Lippincott Williams \& Wilkins).

GIBSON, M. (2007) Ophthalmic dosage forms, IN: M. Gibson (Ed.) Pharmaceutical preformulation and formulation, pp. 459-489 (New York: Informa).

GIRI, T. K., PARVEEN, N., THAKUR, D., ALEXANDER, A., BADWAIK, A. H. \& TRIPATHI, D. K. (2012) In vitro evaluation of commercially available enteric coated tablet containing diclofenac sodium, International Journal of Research in Pharmaceutical and Biomedical Sciences, 3(2): 875-881.

HAMAM, H. A. B. (2014) Comparative in vitro evaluation of generic ciprofloxacin hydrochloride tablets, World Journal of Pharmacy and Pharmaceutical Sciences, 3(12): 388-390. http://dx.doi.org/10.13040/IJPSR.0975-8232.1(8).51-57

Malay J Pharm Sci, Vol. 19, No. 2 (2021): 73-86 
HSU, H. \& AYRES, J. W. (1989) Chlorpheniramine dissolution and relative urinary exerction from commercial products, Journal of Pharmaceutical Sciences, 78(10): 844-847. https://doi.org/10.1002/jps.2600781013

HYATT, J. M., NIX, D. E. \& SCHENTAG, J. J. (1994) Pharmacokinetic and pharmacodynamic activities of ciprofloxacin against strains of Streptococcus pneumoniae, Staphylococcus aureus and Pseudomonas aeruginosa for which MICs are similar, Antimicrobial Agents and Chemotherapy, 38(12): 2730-2737. http://doi.org/10.1128/AAC.38.12.2730

ITIOLA, O. A. \& PILPEL, N. (1996) Effects of interacting variables on the disintegration and dissolution of metronidazole tablets, Pharmazie, 51: 987-989.

JOHNSTON, A. \& HOLT, D. W. (2014) Substandard drugs: A potential crisis for public health, British Journal of Clinical Pharmacology, 78(2): 218-243. https://doi.org/10.1111/ bcp.12298

LACHMAN, L., LIBERMAN, H. \& KANIG, J. (1986) The theory and practice of industrial pharmacy, $3^{\text {rd }}$ edition, pp. 293-373 (Philadelphia: Lea \& Febiger).

LODE, H. \& ALLEWELT, M. (2002) Role of newer fluoroquinolones in lower respiratory tract infections, Journal of Antimicrobial Chemotherapy, 49(5): 709-712. https://doi.org/10.1093/ $\mathrm{jac} / \mathrm{dkf133}$

MERCHANT, H. A., SHOIAB, H. M., TAZEEN, J. \& YOUSUF, R. I. (2006) Once-daily tablet formulation and in vitro release evaluation of cepfodoxime using hydroxypropyl methylcellulose: A technical note, Journal of American Association of Pharmaceutical Scientists, 7(3): E178-E183. https://doi.org/10.1208/pt070378

NAVEED, S. \& WAHEED, N. (2014) Simple UV spectrophotometric assay of ciprofloxacin, Mintage Journal of Pharmaceutical and Medical Science, 3(4): 10-13.

NIAZI, S. K. (2007) Handbook of bioequivalence testing, $1^{\text {st }}$ edition (New York: Informa Healthcare).

OFORI-KWAKYE, K., OSEI-YEBOAH, F. \& KIPO, S. L. (2010) Formulation and quality evaluation of two conventional release tablet formulations, International Journal of Pharmaceutical Sciences Review and Research, 4(1): 94-99.

PECOUL, B., CHIRAC, P., TROUILLER, P. \& PINEL, J. (1999) Access to essential drugs in poor countries: A lost battle? American Medical Association, 281: 361-367.

RAO, N. R. \& NAGARAJU, V. (2004) Separation and determination of synthetic impurities of norfloxacin by reversed-phase high performance liquid chromatography, Journal of Pharmaceutical and Biomedical Analysis, 34(5): 1049-1056. https://doi.org/10.1016/j. jpba.2003.11.009

RAWLINS, E. A. (1977) Bentley's text book of pharmaceutics, $8^{\text {th }}$ edition, pp. 289-290 (London: Bailliere Tindal Publisher). 
SALLAMI, Z., KASSIM, Y., SELVARAJ, J., PARRY, E. \& WINTER, G. ( 2017) Impact of the armed conflict of 2015-2016 in Aden on health services and the availability of medicines, Health, 9: 685-696. http://creativecommons.org/licenses/by/4.0/

SHAH, V. (2001) Dissolution: A quality control test vs a bioequivalent test, Dissolution Technologies, 8(4): 1-2. http://doi.org/10.14227/DT080401P6

SWARBRICK, J. (2007) Encyclopedia of pharmaceutical technology, $3^{\text {rd }}$ edition (New York: Informa Healthcare).

THE UNITED STATES PHARMACOPEIA (2007) National formulary, Vol. 4, Uniformity of dosage units (905), p. 736 (Rockville (MD): United States Pharmacopeial Convention).

THE UNITED STATES PHARMACOPEIA (2016) National formulary, Vol. 2, Ciprofloxacin, p. 3164. (Rockville (MD): United States Pharmacopeial Convention).

UDDIN, M. S., MAMUN, A. A., TASNU, T. \& ASADUZZAMAN, M. (2015) In-process and finished products quality control tests for pharmaceutical tablets according to pharmacopoeias, Journal of Chemical and Pharmaceutical Research, 7(9): 180-185. https://doi.org/10.9734/BJPR/2016/22044

UDUMA, E. O., AYODEJI, A. A., ROSEMARY, C. A., OKORIE, O. \& CHRISTIAN, C. O. (2011) Bioequivalence studies on some selected brands of ciprofloxacin hydrochloride tablets in the Nigerian market with ciproflox $®$ as innovator brand, Journal of Applied Pharmaceutical Sciences, 1(6): 81-83.

VERPOORTE, R. \& MUKHERJEE, P. K. (2003) GMP for botanicals: Regulatory and quality issues on phytomedicines, pp. 383-383 (New Delhi: Business Horizons).

WORLD HEALTH ORGANIZATION (WHO) (2018) High levels of antibiotic resistance found worldwide, new data shows. https://www.who.int/mediacentre/news/releases/2018/ antibiotic-resistance-found/en/ (14 July 2020).

WORLD HEALTH ORGANIZATION (WHO) (2005) Regional strategy for improving access to essential medicines in the Western Pacific Region 2005-2010 (Geneva: World Health Organization).

WORLD HEALTH ORGANIZATION (WHO) (1996) Technical report series 863. Expert committee on specifications for pharmaceutical preparations: 34 th report (Geneva: World Health Organization).

Malay J Pharm Sci, Vol. 19, No. 2 (2021): 73-86 